\title{
Relationship Practical Experince and Knowledge With Implementing Health Protocol During Pandemic Covid-19 Among Midwives in Bekasi District
}

\author{
Herlina Simanjuntak $^{1 *}$, Hajar Nur Fathur Rohmah ${ }^{1}$ \\ Diploma of Midwifery, Institut Medika Drg. Suherman, Cikarang, Kabupaten Bekasi, 17534, Indonesia \\ *Corresponding Author : Email. herlina.simanjuntak09@gmail.com
}

\begin{abstract}
COVID-19 has been declared as the world pandemic and also as an outbreak of non-natural disasters in Indonesia. The government has made health service policies and protocols, especially maternal and child health services. Midwives are at the forefront and health workers that most often encountered by the community in maternal and child health services. In an effort to minimize local transmission COVID-19 midwives should know and apply health protocols in implementing midwifery practices. The aimed of this study was to determine the relationship of practical experience and knowledge with the implement of maternal and newborn health care protocols during the COVID-19 pandemic. The research method used is descriptive analytic with cross sectional approach. The population in this study were all midwives in Bekasi District, the sample was midwives who carried out practices in Bekasi District with a total of 114 respondent, with a purposive sampling technique. The research instrument used was an online questionnaire sent via electronic message. The results shown that $70.8 \%$ of midwives who had good knowledge applied health care protocols well, 52.8\% of midwives who had high experience of implementing health care protocols well. Thus the results show there is a relationship between knowledge and the implement of maternal and newborn health protocols during the Covid-19 pandemic ( $\mathrm{p}$-value 0.000 ), but practical experience has no relationship with the implement of the protocol (p-value 0.843). The conclusions of the study found, midwives in Bekasi District who have good knowledge was implementing health care protocols well, but there was no relationship shown between experience and implementing health protocol. It is recommended that during the Pandemics COVID 19, midwives should increase their knowledge, so that they are able to implement the protocol for preventing COVID-19 transmission in midwifery practice services. Keywords: implementing health protocol, knowledge, practical experience
\end{abstract}

\section{INTRODUCTION}

The world is experiencing a global health problem which was later declared a pandemic by the World Health Organization (WHO) on March 11, 2020 which was caused by severe acute respiratory syndrome coronavirus 2 (SARS-CoV2) or known as Coronavirus Disease (COVID-19). The spread of COVID-19 has covered almost all countries, including Indonesia.[1] This pandemic was also declared an epidemic of non-natural disasters in Indonesia. According to the WHO report, the number of cases in the world as of 9 July 2020 was $1,184,226$ confirmed cases and 545,481 death cases with a Case Fatality Rate of 4.6\%.[2]

There were 70,736 cases of COVID-19 confirmation in Indonesia reported by the Indonesian Ministry of Health until July 92020 and the number of cases died 3,417 with a Case Fatality Rate of $4.8 \%$. If we compare it to the world's Case Fatality Rate, the percentage in Indonesia is $0.2 \%$ higher.[3] The government has made efforts to control and prevent the spread of COVID-19, while waiting for drugs and vaccines to be found as a cure 
and protection. One of the efforts made by providing education about physical distancing, washing hands with soap or using a hand sanitizer, using personal protective equipment, and other health service protocols to the wider community, especially health workers.[4]

Midwives are health workers who provide maternal and child health services as the front line. This can be seen from the percentage of antenatal care, delivery and midwifery service for newborns. Midwives are the health workers most visited by the community for antenatal care $82.4 \%$, delivery $62.7 \%$ and newborn service providers $51 \%$.[5] Therefore, midwives should have good knowledge about the prevention of transmission and spread of COVID-19 during the pandemic. Good knowledge will be the basis for a person to implement good health behaviors.[6]

It is hoped that the health service protocols that have been established by the government can be implemented by midwives with high experience or young midwives. The changes to care all designed to reduce the COVID-19 infection risk for pregnant women and staff, and whilst phone and online consultations can be acceptable and valued by women as an interim measure. Another area variation is postnatal care. WHO COVID-19 guidance has consistently promoted continues skin to skin contact and breastfeeding also asked women to wear face mask and take hygiene precautions to reduce the risk transmission to baby.[7]

Bekasi district has high COVID-19 cases and midwifery services have been affected by the COVID-19 pandemic.[8] However, the COVID-19 pandemic has led to midwifery services how to provide maternal and neonatal health care due to the government restrictions regarding social distancing, which impact on patient access to midwifery services. While there are limited research results that have published knowledge and practical experience regarding the implementation of protocols for maternal and newborn health services during the COVID-19 pandemic era. Therefore, researchers are interested in conducting research on the practical experience and knowledge of midwives by implementing the protocols for maternal and newborn health services in the era of the COVID-19 pandemic in Bekasi Regency.

\section{METHOD}

This research is a quantitative analytic, while the approach used is cross-sectional. This research was conducted from 20 May 2020 to 19 July 2020. The research population is the whole subject of research to be studied, so that the population in this study is a midwife who practices in the Bekasi district. The sampling technique used was purposive sampling, which is a technique that is carried out nonrandomly and in accordance with the research objectives that meet the inclusion criteria of the researcher, as many as 114 people. The inclusion criteria of this study were midwives registered as members of the Bekasi District Indonesian Midwives Association who had a device to fill out a questionnaire online. While the exclusion criteria for this study were midwives who did not fill in complete data on the online questionnaire via google form and did not give midwifery services during the COVID-19 pandemic. Data were analyzed by univariate and bivariate, the results of univariate analysis were to determine the presentation of each dependent variable and the independent variable. Bivariate analysis using the chi-square test to determine the relationship between the independent variable and the dependent variable, which are practical experience and knowledge of implementing protocols for maternal and newborn health services during the COVID-19 pandemic.

\section{RESULTS}

\subsection{Univariate Analysis Results}

Table 1 Distribution of Practical Experience and Knowledge of Midwives during the COVID-19 Pandemic Era in Bekasi District

\begin{tabular}{lcc}
\hline Variable & f & \% \\
\hline Practical & & \\
experience & & \\
$<10$ tahun & 25 & 21.9 \\
$\geq 10$ tahun & 89 & 78.1 \\
\hline Total & $\mathbf{1 1 4}$ & $\mathbf{1 0 0}$ \\
Knowledge & & \\
Poor & 49 & 42.9 \\
Good & 65 & 57.1 \\
\hline Total & $\mathbf{1 1 4}$ & $\mathbf{1 0 0}$ \\
\hline
\end{tabular}

Tables 1 show the distribution of knowledge of midwives and experience of midwives in Bekasi District. The most experienced midwife practice was more than 10 years, namely $78.1 \%$ or 89 respondents. Meanwhile, the knowledge of midwives in Bekasi District about the protocol for maternal and newborn health services was mostly good, namely $57.1 \%$ or 65 respondents. 


\subsection{Results of Bivariate Analysis}

Table 2 Relationship between Practical Experience and Implementation of Protocols for Maternal and Newborn Health Services in the Covid-19 Pandemic Era

\begin{tabular}{|c|c|c|c|c|c|c|c|}
\hline \multirow{2}{*}{$\begin{array}{c}\text { Practic } \\
\text { al } \\
\text { experi } \\
\mathrm{e}\end{array}$} \\
\cline { 3 - 6 } \begin{tabular}{c} 
nce \\
\cline { 2 - 6 }
\end{tabular} & \multicolumn{2}{|c|}{ poor } & \multicolumn{2}{|c|}{ good } & \multicolumn{2}{|c|}{ total } & $\begin{array}{c}P \\
\text { Value }\end{array}$ \\
\cline { 2 - 7 } & $\mathrm{n}$ & $\mathrm{n}$ & $\%$ & $\mathrm{n}$ & $\%$ & \\
\hline \hline$<10$ th & 13 & 52 & 12 & 48 & 25 & 100 & 0.843 \\
\hline$>10$ th & $\underline{42}$ & $\underline{47.2}$ & $\underline{47}$ & $\underline{52.8}$ & $\underline{89}$ & $\underline{100}$ & \\
\hline \hline
\end{tabular}

Table 2 shows that as many as 89 midwives have practical experience for more than 10 years. Of these 47 midwives $(52.8 \%)$ had implemented the COVID-19 prevention protocol well. Meanwhile, 25 midwives with less than 10 years of practical experience and 52\% less implement the COVID-19 prevention protocol. The statistical test show $\mathrm{p}$ value $=0.843>0.05$, which means that there is no relationship between practical experience and the implementation of the COVID-19 prevention protocol.

Table 2 the relationship Knowledge with the Implementation of Protocols for Maternal and Newborn Health Services in the COVID-1 9 Pandemic Era

\begin{tabular}{|c|c|c|c|c|c|c|c|}
\hline \multirow{3}{*}{$\begin{array}{c}\text { Knowl } \\
\text { edge }\end{array}$} & \multicolumn{4}{|c|}{ Implement of protocol } & \multirow{2}{*}{\multicolumn{2}{|c|}{ total }} & \multirow{2}{*}{$\begin{array}{c}P \\
\text { Value }\end{array}$} \\
\hline & \multicolumn{2}{|c|}{ poor } & \multicolumn{2}{|c|}{ good } & & & \\
\hline & $\mathrm{n}$ & $\%$ & $\mathrm{n}$ & $\%$ & $\mathrm{n}$ & $\%$ & \\
\hline poor & 36 & 73.5 & 13 & 26.5 & 49 & 100 & 0.000 \\
\hline good & 19 & 29.2 & 46 & 70.8 & 65 & 100 & \\
\hline
\end{tabular}

Table 3 shows that as many as 65 midwives have good knowledge of COVID-19 prevention protocols. Of these 46 midwives $(70.8 \%)$ have implemented the COVID-19 prevention protocol properly. Meanwhile, there were 49 midwives who had insufficient knowledge and $73.5 \%$ less implement the COVID-19 prevention protocol. The statistical test show $\mathrm{p}$ value $=0.001<0.05$, which means that there is a relationship between knowledge and the application of the COVID-19 prevention protocol.

\section{DISCUSSIONS}

Experience can be interpreted as something that has been experienced, lived and felt, both long and long ago just happened.[6] The results obtained are not in accordance with the behavioral theory put forward by Lawrence and Green, that health behavior is influenced by factors of education, knowledge, attitudes, experience, economy, age and so on. However, the results of this study are in line with the results of research by Sutresno et al., Where the work experience of midwives has no effect on behavior towards cervical cancer prevention in Sragen Regency.[9] Thus can be influenced by other supporting factors. The pandemic is a new thing to our country, even the whole world. As we know that the health workers do not have sufficient preparation to deal with it. It is probably that midwives have not had fully awareness to apply this protocols. The midwives should be more responsive and adaptive to the changes that occur, especially regarding information and prevention spread of COVID-19.

Knowledge is the result of knowing and this happens after someone senses an object. Sensing occurs through the human senses, namely, the senses of hearing, sight, smell, feeling and touch.[6] The results of this study are in accordance with the theory that knowledge is the basis for someone to behave. Good knowledge makes someone have the ability to do a good behavior.[10] Midwives are trained to perform self-protection tools according to the recommendation of the Ministry of Health. In addition, midwives are advised to ensure that they carry out a travel history assessment or close contact with confirmed case patients. In addition, midwives are advised to postpone classes for pregnant women and children under five or divert them online.[11]

This is in line with research conducted by Airubaiee et all, that good knowledge of COVID-19 has a significant relationship with active behavior among health workers in preventing transmission of COVID-19. According to the WHO report, by implementing 6-step hand washing with soap for at least 20 seconds can kill microorganisms and viruses because the fat layer of COVID-19 will be damaged. In addition, the use of medical masks for patients with respiratory symptoms is effective in preventing transmission of the virus. Avoiding crowds and maintaining distance is believed to be able to minimize the spread of COVID-19 because this virus is transmitted through droplets.[12]

\section{CONCLUSION}

Good knowledge of midwives has a significant relationship with the implementation of good health protocols for mothers and newborns during the COVID-19 pandemic era in Bekasi District. Experience of more than 10 years does not guarantee that someone applies the behavior of implementing the COVID-19 prevention protocol, in this study practical experience does not have a 
significant relationship with the application of health protocols. In accordance with the government's appeal and policy that health workers, especially midwives, can synergize with the government in reducing the spread of COVID-19 so that confirmation cases in the future can be diminished. It is recommended that midwives can improve the latest knowledge about COVID-19 by reading government and following online webinars organized by professional organizations and health experts.

\section{ACKNOWLEDGMENT}

We would like to thank the Rector of the Institut Medika Drg. Suherman Dr. Triseu Setianingsih, S.KM., M.KM and Chairman of the Medika Foundation Drg. Dr. Suherman drg. Eddy Suharso, SH., M.Kes who has provided support to researchers so that this research can be carried out. We would to thank the head of the Indonesian Midwives Association for Bekasi District, $\mathrm{Hj}$. Nursiati PN, S.SiT., MM who has provided direction and permission to conduct research on the IBI members of Bekasi District. Hopefully the results of this research can provide benefits for all parties and have a good impact on the quality of health services, especially maternal and child health services in the era of the COVID-19 pandemic.

\section{REFERENCES}

[1] D. Kumar, "Corona Virus: A Review of COVID-19," Eurasian J. Med. Oncol., 2020, doi: 10.14744/ejmo.2020.51418.

[2] W. H. Organization, "Coronavirus disease (COVID-19) pandemic,” 2020.

https://www.who.int/emergencies/diseas es/novel-coronavirus

2019? gclid=Cj0KCQjw3s_4BRDPARIs AJsyoLNSDDB17nkM23cop0eu1jeFKt m7d89hBqfIfQ93zIU3LU0JCI_SUawa ArGLEALw_wcB (accessed Jul. 09, 2020).

[3] Kemenkes RI, Buku Pedoman Pemberdayaan masyarakat dalam pencegahan COVID-19. 2020.

[4] W. H. Organization, "Advice on the use of masks in the context of COVID-19," 2020 . https://apps.who.int/iris/bitstream/handl e/10665/332293/WHO-2019-nCov-

IPC_Masks-2020.4-eng.pdf (accessed Jul. 09, 2020).

[5] Kementerian Kesehatan RI, "Hasil Utama Riskesdas,” 2018. https://kesmas.kemkes.go.id/assets/uplo ad/dir_519d41d8cd98f00/files/Hasilriskesdas-2018_1274.pdf (accessed Oct. 02, 2020).

[6] S. Notoatmodjo, Ilmu Perilaku Kesehatan. Jakarta: Rineka Cipta, 2014.

[7] K. Coxon et al., "The impact of the coronavirus (COVID-19) pandemic on maternity care in Europe," Midwifery. 2020, doi:10.1016/j.midw.2020.102779.

[8] K. Bekasi, "Gugus Tuga Percepatan Penanganan COVID-19 Kabupaten Bekasi,” 2020. https://pikokabsi.bekasikab.go.id/.

[9] I. J. Sutresno, O. Emilia, and S. Prawitasari, "Hubungan pengetahuan bidan desa terhadap kanker leher rahim dan pencegahannya di Kabupaten Sragen," J. Kesehat. Reproduksi, vol. 4, no. 1, p. 11, Apr. 2017, doi: 10.22146/jkr.35429.

[10] H. Simanjuntak, B. W. Lestari, and A. D. Anwar, "The effect of structured counseling towards knowledge, attitude, and participation of modern contraceptive among unmet need couples," Kesmas, vol. 10, no. 4, pp. 184-190, Jun. 2016, doi: 10.21109/kesmas.v10i4.644.

[11] K. Republik Indonesia, Pedoman Bagi Ibu Hamil, Bersalin, Nifas dan Bayi Baru Lahir di Era Pandemi COVID-19. Jakarta: Kemenkes, 2020.

[12] World Health Organization, "Infection prevention and control during health care when COVID-19 is suspected," WHO/2019-nCoV/IPC/2020.3, 2020. https://apps.who.int/iris/bitstream/handl e/10665/331495/WHO-2019-nCoVIPC-2020.3-eng.pdf (accessed Oct. 02, 2020). 